\title{
DYNAMICS OF A COMBINED DOC-NSRC-SCR EXHAUST GAS AFTERTREATMENT SYSTEM WITH PERIODIC REGENERATIONS
}

\author{
František Plát, Šárka Bártová, Jan Štěpánek, Petr Koči and Miloš Marek \\ Institute of Chemical Technology, Prague, Department of Chemical Engineering, \\ Technická 5, CZ 16628 Praha, Czech Republic
}

\section{Summary}

A combined exhaust gas after-treatment system is studied, consisting of a Diesel oxidation catalyst (DOC), an $\mathrm{NO}_{\mathrm{x}}$ storage and reduction catalyst (NSRC, also called lean $\mathrm{NO}_{\mathrm{x}}$ trap, LNT), and a catalyst for selective catalytic reduction of $\mathrm{NO}_{\mathrm{x}}$ by $\mathrm{NH}_{3}\left(\mathrm{NH}_{3}\right.$-SCR). The catalyst samples are located in series in a nearly isothermal lab mini-reactor. Dynamic behavior of the system is examined in periodic lean/rich operation at different temperatures. Gas components concentrations are measured at the inlet, outlet, and in between the individual catalysts. Conversions, selectivities and reaction mechanisms in each converter are discussed.

Keywords

Environmental reaction engineering, Diesel emission control, Dynamics and control of chemical reacting systems.

\section{Introduction}

Abatement of the $\mathrm{NO}_{\mathrm{x}}$ emissions from fuel-efficient Diesel engines is a complicated task - a direct $\mathrm{NO}_{\mathrm{x}}$ reduction is hindered under the oxidizing conditions that prevail in the Diesel exhaust gas. A special deNO ${ }_{x}$ catalytic converter is necessary to meet the most strict emission limits. ${ }^{1,2}$

Two technologies for the elimination of the $\mathrm{NO}_{\mathrm{x}}$ emissions from lean-burn engines are nowadays used commercially in automotive industry: $\mathrm{NO}_{\mathrm{x}}$ storage and reduction catalyst (NSRC, called also lean $\mathrm{NO}_{\mathrm{x}}$ trap, LNT), and selective catalytic reduction of $\mathrm{NO}_{\mathrm{x}}$ by $\mathrm{NH}_{3},{ }^{1,2}$

The $\mathrm{NH}_{3}$-SCR catalyst needs an external source of the selective reducing agent (ammonia). The vehicle is usually equipped with a special tank containing urea solution. The urea is injected into the exhaust line, where it is thermally decomposed into $\mathrm{NH}_{3}$ and $\mathrm{CO}_{2}$. The ammonia then reacts selectively with $\mathrm{NO}_{\mathrm{x}}$ under lean (oxidizing) conditions, giving $\mathrm{N}_{2}$ as the final product. ${ }^{1}$ Mainly $\mathrm{V}_{2} \mathrm{O}_{5} / \mathrm{WO}_{3} / \mathrm{TiO}_{2}$ or zeolite formulations (Fe-ZSM5 and $\mathrm{Cu}$-ZSM5) are currently used in automobile applications. ${ }^{2}$

The NSRC converter must be operated with periodic regenerations, i.e., temporarily increased concentration of the reducing components normally present in the exhaust gas $\left(\mathrm{CO}, \mathrm{H}_{2}\right.$ and $\left.\mathrm{HC}\right)$. In the course of a longer lean phase (lasting several minutes) the $\mathrm{NO}_{\mathrm{x}}$ are adsorbed on the catalyst surface. The accumulated $\mathrm{NO}_{\mathrm{x}}$ then need to be reduced within a controlled short rich phase (lasting several seconds). ${ }^{1,2}$ Typical formulation of the NSRC catalyst is $\mathrm{NM} / \mathrm{EA} / \mathrm{OS} / \gamma-\mathrm{Al}_{2} \mathrm{O}_{3}(\mathrm{NM}=$ noble metals $\mathrm{Pt}$, $\mathrm{Rh}$; $\mathrm{EA}=$ (earth) alkaline metals for the $\mathrm{NO}_{\mathrm{x}}$ chemisorption; $\mathrm{OS}=$ oxygen storage compounds, typically Ce oxides). ${ }^{1,2,3}$

Besides nitrogen, the desired main product of the $\mathrm{NO}_{\mathrm{x}}$ reduction, also significant amount of $\mathrm{NH}_{3}$ can be formed in the NSRC depending on the regeneration phase length, temperature and gas composition. ${ }^{3}$ In a stand-alone NSRC, the regenerations need to be properly calibrated with respect to actual catalyst conditions to avoid excessive $\mathrm{NH}_{3}$ formation. ${ }^{3}$ However, there is a possibility to advantageously combine the ammonia generation in the $\mathrm{NSRC}$ with the ammonia utilization in the $\mathrm{SCR}^{4,5}$

In any case, a Diesel oxidation catalyst (DOC) is used as the first element in the exhaust after-treatment line. It is responsible for the oxidation of $\mathrm{CO}$ and unburned hydrocarbons (HC). The DOC is based on $\mathrm{NM} / \gamma-\mathrm{Al}_{2} \mathrm{O}_{3}$ formulation and usually contains also compounds for $\mathrm{HC}$ adsorption during a cold start (typically zeolites). ${ }^{6}$

\footnotetext{
${ }^{*}$ To whom all correspondence should be addressed. E-mail: petr.koci@vscht.cz, http://www.vscht.cz/monolith
} 


\section{Experimental set-up}

Dynamic behavior of a combined DOC-NSRC-SCR exhaust gas after-treatment system is studied during periodic lean/rich operation. Three small $\left(\approx 3 \times 3 \times 0.5 \mathrm{~cm}^{3}\right)$ catalytic monolith bricks (commercially available DOC, NSRC and SCR) are located in series in a nearly isothermal lab mini-reactor.

Mixture of synthetic gases $\left(\mathrm{CO}, \mathrm{O}_{2}, \mathrm{C}_{3} \mathrm{H}_{6}, \mathrm{H}_{2}, \mathrm{NO}, \mathrm{NO}_{2}\right.$, $\mathrm{CO}_{2}, \mathrm{H}_{2} \mathrm{O}$ and $\mathrm{N}_{2}$ ) is used to approximate the real exhaust composition. Two independent inlet lines and a fast switching valve are employed to enable rapid changes between the lean and the rich mixture. Temperatures and components concentrations (including $\mathrm{NH}_{3}$ and $\mathrm{N}_{2} \mathrm{O}$ ) are measured at the inlet, outlet, and in between the individual catalysts.

\section{Results and discussion}

The measured dynamic evolution of reactants and products at different positions in the DOC-NSRC-SCR system is used for the evaluation of conversions and selectivities in individual catalysts, as well as for the discussion of key reactions and functionalities of each converter.

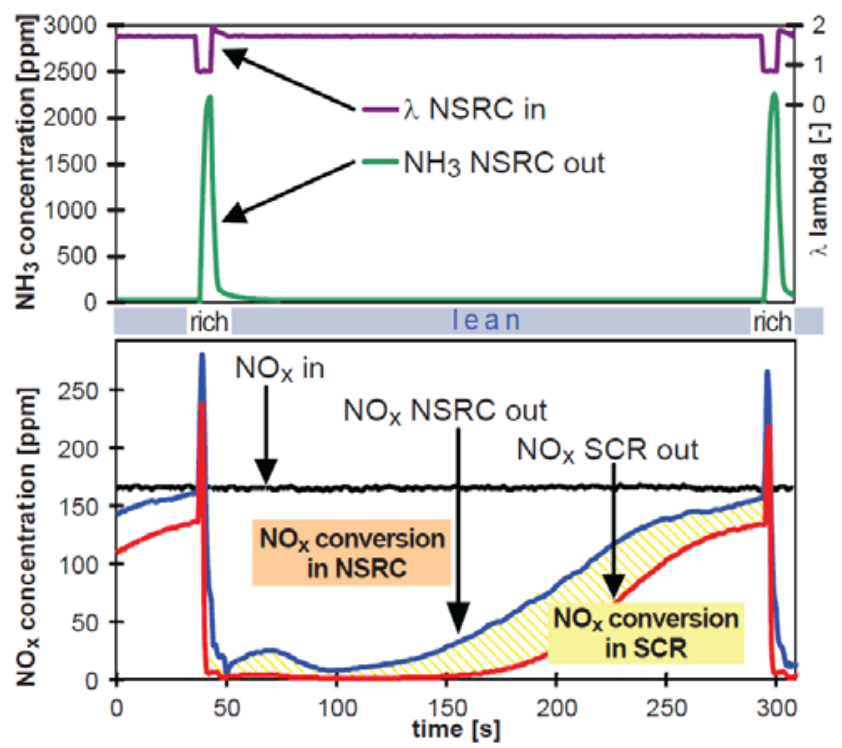

Figure 1. Typical evolution of $\mathrm{NO}_{\mathrm{x}}$ and $\mathrm{NH}_{3}$ concentrations at different positions in the combined system. ${ }^{5}$

Several synergistic effects can be observed in the combined DOC-NSRC-SCR system, e.g.:

- $\mathrm{NO}$ oxidation to $\mathrm{NO}_{2}$ in the DOC improves the $\mathrm{NO}_{\mathrm{x}}$ storage in the NSRC at lower temperatures.

- Hydrogen, an effective $\mathrm{NO}_{\mathrm{x}}$ reducing agent, can be produced in the DOC from $\mathrm{CO}$ and $\mathrm{C}_{3} \mathrm{H}_{6}$ via water gas shift and steam reforming under rich conditions.

- Ammonia, formed in the NSRC as a by-product of the $\mathrm{NO}_{\mathrm{x}}$ reduction under rich conditions, is adsorbed in the SCR and used for additional $\mathrm{NO}_{\mathrm{x}}$ reduction in a consequent lean phase.
- The $\mathrm{NO}$ oxidation to $\mathrm{NO}_{2}$ that takes place in both $\mathrm{DOC}$ and NSRC enables the fast SCR reaction in the SCR converter.

On the other hand, some competitive effects can be found as well in the DOC-NSRC-SCR system, e.g.:

- A part of the reducing agents in the rich pulse that are intended for the $\mathrm{NO}_{\mathrm{x}}$ reduction in the NSRC are consumed already in the DOC.

- At lower temperatures the NSRC can decrease the $\mathrm{NO}_{2} / \mathrm{NO}_{\mathrm{x}}$ ratio by the $\mathrm{NO}_{2}$ disproportion route of the $\mathrm{NO}_{\mathrm{x}}$ storage, and thus limit the extent of the fast SCR reaction in the SCR converter.

\section{Conclusions}

The studied DOC-NSRC-SCR configuration represents one of the complex Diesel exhaust gas after-treatment systems that are used to meet the strict regulations of gaseous emissions. ${ }^{1,2,4,5}$ In practical application these converters are combined yet with a Diesel particulate filter (DPF) for elimination of soot emissions. ${ }^{4,5}$ A single catalytic converter itself represents a complex, non-linear system. Proper design and control of several interconnected catalytic devices of various types under transient operation is a demanding task. Therefore it is necessary to study systematically the combined systems by both experiments and mathematical modeling ${ }^{1,3,4,5,6}$, and to identify the ways how the catalytic converters influence each other.

\section{References}

(1) Güthenke A., Chatterjee D., Weibel M., Krutzsch B., Kočí P., Marek M., Nova I., Tronconi E. Current status of modelling lean exhaust gas aftertreatment catalysts. Advances in Chemical Engineering 2007, 33, 103-211.

(2) Dieselnet, http://www.dieselnet.com 2009.

(3) Kočí P., Plát F., Štěpánek J., Bártová Š., Marek M., Kubíček M., Schmeißer V., Chatterjee D., Weibel M. Global kinetic model for the regeneration of $\mathrm{NO}_{\mathrm{x}}$ storage catalyst with $\mathrm{CO}, \mathrm{H}_{2}$ and $\mathrm{C}_{3} \mathrm{H}_{6}$ in the presence of $\mathrm{CO}_{2}$ and $\mathrm{H}_{2} \mathrm{O}$. Catalysis Today 2009, 147S, S257-S264.

(4) Weibel M., Waldbüßer N., Wunsch R., Chatterjee D., Bandl-Konrad B., Krutzsch B. Topics in Catalysis 2009, 52, 1702-1708.

(5) Chatterjee D., Kočí P., Schmeißer V., Marek M., Weibel M., Krutzsch B. Modelling of combined $\mathrm{NO}_{\mathrm{x}}$ storage and $\mathrm{NH}_{3}-\mathrm{SCR}$ catalytic system for Diesel exhaust gas aftertreatment. Catalysis Today 2010, submitted.

(6) Kryl D., Kočí P., Kubíček M., Marek M., Maunula T., Härkönen M. Catalytic Converters for Automobile Diesel Engines with Adsorption of Hydrocarbons on Zeolites. Industrial and Engineering Chemistry Research 2005, 44, 9524-9534. 